\title{
Penerapan Metode Pembelajaran Inkuiri DAN Group Investigation Pada Pembelajaran PJOK Terhadap Partisipasi Dan Berpikir Kritis Siswa SMPN 4 Pamekasan
}

\author{
${ }^{1}$ Eka Cahyadi, ${ }^{2}$ Agus Hariyanto, ${ }^{3}$ Dwi Cahyo Kartiko \\ Email: ecahyadi433@gmail.com
}

\begin{abstract}
Abstrak. Penelitian ini bertujuan untuk menganalisis pengaruh metode inkuiri dan group investigation terhadap partisipasi dan berpikir kritis siswa SMPN 4 Pamekasan. Desain penelitian ini meggunakan non randomized control group pretest- posttest design untuk mengetahui peningkatan partisipasi dan berpikir kritis. Hasil penelitian menunjukkan grafik partisipasi pada kelompok Inkuiri meningkat sebesar 5,0\%, pada kelompok Group Investigation sebesar 7,3\%, dan pada kelompok kontrol sebesar 3,6\%. Grafik berpikir kritis menunjukan peningkatan sebesar 8,8\% pada kelompok Inkuiri, 15,2\% pada kelompok Group Investigation, dan 1,4\% pada kelompok Kontrol. Uji beda paired sample t test kelompok Inkuiri (0,006), Group Investigation (0,000), pada kelompok kontrol (0,052), pada kelompok penelitian menunjukkan nilai <0,05, maka $H_{0}$ ditolak, sedangkan kelompok kontrol menunjukkan nilai > 0,05, maka $H_{0}$ diterima, yang berarti ada perbedaan partisipasi pada pretest dan posttest ketiga kelompok tersebut. Uji paired sample t test pada berpkir kritis kelompok Inkuiri (0,000), Group Investigation (0,000) menghasilkan < 0,05 maka $H_{0}$ ditolak sehingga ada perbedaan yang signifikan pada berpikir kritis siswa, sedangkan kelompok kontrol (0,327) tidak. Berdasarkan hasil ini disimpulkan bahwa metode pembelajaran inkuiridan group investigation terhadap partisipasi di SMPN 4 pamekasan, terdapat pengaruh yang signifikan pada kelas yang di ambil sampelnya, tapi yang lebih signifikan pada kelas group investigation.
\end{abstract}

Kata Kunci: Metode Inkuiri, Group Investigation, Partisipasi, Berpikir Kritis

\section{PENDAHULUAN}

Kualitas kehidupan bangsa ditentukan oleh faktor pendidikan. Oleh karena itu, pembaharuan pendidikan harus selalu dilakukan untuk meningkatkan kualitas pendidikan nasional. Upaya peningkatan mutu pendidikan itu diharapkan dapat menaikkan harkat dan martabat masyarakat Indonesia. Untuk mencapai itu pendidikan harus adaptif terhadap perubahan zaman. Perkembangan bangsa sangat ditentukan oleh kualitas sumber daya manusia (SDM) yang ada, sehingga diperlukan penerus terbaik bangsa yang memiliki kecerdasan tinggi, sikap dan mental prima, daya juang dan daya saing tinggi, kemampuan yang handal serta nasionalisme sejati. (BKLN Kemendikbud, 2011, p.1). Proses pembelajaran seringkali berorientasi pada terselesaikannya materi pembelajaran saja bukan pada ketercapaian tujuan pembelajaran yakni peningkatan kompetensi siswa. Kompetensi diantaranya hasil belajar maupun kemandirian siswa dalam pembelajaran. Dapat diartikan bahwa modelmodel pembelajaran yang diterapkan selama ini cenderung terlalu teoritik dan merupakan peningkatan kompetensi pada diri siswa.

Pendidikan Jasmani Olahraga dan Kesehatan (PJOK) merupakan salah satu mata pelajaran yang diberikan kesekolah mulai dari SD, SMP, hingga SMA. Pembinaan PJOK diusahakan untuk membentuk jasmani yang sehat mental yang baik, supaya menghasilkan siswa yang baik. Sedangkan pembinaan olahraga disarankan untuk menumbuhkan minat dan bakat siswa agar dapat mencapai prestasi olahraga yang optimal. Pencapaian siswa terhadap tujuan PJOK sangat erat kaitannya dengan kemampuan guru dalam mengelola kegiatan pembelajaran. Di dalam mengajar guru diperlukan strategi dan metode yang menarik untuk memudahkan siswa dalam penguasaan materi pelajaran yang disampaikan oleh guru. Dengan demikian diharapkan materi yang diterima dapat tersimpan dalam waktu yang relatif lama dalam ingatan siswa. Untuk menjalankan proses pembelajaran PJOK, kegiatan belajar dan pembelajaran merupakan suatu usaha yang amat strategis untuk mencapai tujuan yang diharapkan (Winatraputra, 1994: 4).

Belajar dianggap fungsi utama otak. Para peneliti menganalisa bahwa tidak ada orang sebelum 1980-an itu menyadari yang terjadi di otak selama belajar. Menurut (Mona Baker, 2011) otak manusia disebut 'kotak hitam'. Namun peserta didik cenderung didasarkan hasil belajar. Kegiatan belajar 
merupakan masalah yang kompleks dan melibatkan keseluruhan aspek psiko dan fisik, bukan saja aspek kejiwaan tetapi juga aspek neurofisiologis. Pada tahap ini siswadihadapkan dengan guruyang berbeda, baik yang menyangkut aspek pembelajaran kognitif, afektif dan psikomotor. Penggunaan model pembelajaran yang kurang tepat dalam proses pembelajaran dapat menimbulkan kejenuhan atau kejenuhan, kurangnya pemahaman konsep, dan monoton sehingga siswa kurang termotivasi untuk belajar. Bagi siswa materi pembelajaran itu menjadi sesuatu yang asing pada mulanya. Oleh karena itu, siswa ada yang ngantuk, bosen dalam belajar, kepengen cepet istirahat atau bermain, dari situ siswa kurang tertarik dalam pembelajaran dan keterlibatan siswa dalam pembelajaran.

Partisipasi siswa sangat penting dalam pelaksanaan proses pembelajaran di kelas. Menurut Taniredja, dkk (2013) partisipasi siswa adalah penyertaan mental dan emosi siswa dalam situasi kelompok yang mendorong siswa untuk mengembangkan daya pikir dan perasaan siswa bagi tercapainya prestasi belajar yang memuaskan. Partisipasi dapat mendorong aktivitas siswa untuk mengikuti pembelajaran dengan baik, selain itu partisipasi dapat membentuk siswa untuk selalu aktif sehingga mereka sadar bahwa ilmu pengetahuandiperoleh melalui usaha yang keras. Dengan meningkatnya partisipasi siswa maka prestasi belajar siswa juga akan semakin meningkat.

Menurut Karim (2014) partisipasi siswa bukan hanya tentang masalah kehadiran atau keikutsertaan siswa dalam pembelajaran melainkan partisipasi langsung siswa dengan guru dan siswa dengan siswa, siswa diharapkan dapat berpartisipasi dalam hal tanya jawab, mengutarakan pendapat, meningkatkan keterampilan dan kebugarannya. dapat terlihat aktifitas fisiknya, yang dimaksud adalah giatnya peserta didik aktif dengan anggota badan, untukmembuat sesuatu, permainan, maupun pekerjaan, ia tidak hanya duduk dan mendengarkan, melihat atau pasif. Jika dikaitkan dengan pembelajaran PJOK, partisipasi bukan hanya tentang masalah kehadiran atau keikutsertaan siswa dalam proses pembelajaran saja melainkan partisipasi langsung antara siswa dengan guru yang berarti bahwaindividu siswa serta turut mengambil bagian dari proses pembelajaran yang diberikan oleh guru baik dalam segi instruksi, perintah maupun gerak selama proses pembelajaran berlangsung.

Salah satu pemikiran tingkat tinggi yang harus dimiliki siswa adalah proses berpikir kritis karna siswa akan melatih untuk menganalisis dan memecahkan masalah. Sedangkan berpikir ada beberapa definisi berpikir kritis menurut beberapa ahli. Fisher (2011) mendefinisikan berpikir kritis sebagai kemampuan untuk menginterpretasikan, menganalisis, dan mengevaluasi ide dan argumen. Kemampuan berpikir kritis saat ini sudah dianggap sebagai kemampuan dasar yang sangat penting untuk dikuasai seperti halnya kemampuan membaca dan menulis. Menurut Pikket dan Foster (dalam Susiyati, 2014), berpikir kritis adalahjenis berpikir lebih tinggi yang bukan hanya menghafal materi tetapi penggunaandan manipulasi bahan-bahan yang dipelajari dalam situasi baru. Menurut Scrivan (Fisher, 2011) berpikir kritis sebagai aktivitas 'keahlian' menginterpretasikan, mengevaluasi hasil observasi dan komunikasi, informasi dan argumen. Nugent dan Vitale (dalam Susiyati, 2014) berpikir kritis melibatkan tujuan, goal-directedberpikir dalam proses pembuatan keputusan berdasarkan bukti dan bukan menebak dalam proses pemecahan masalah ilmiah. Dari definisi-definisi tersebut dapat disimpulkan bahwa berpikir kritis adalah kemampuan untuk menafsirkan, menganalisis, mengevaluasi (suatu ide, hasil observasi, informasi, ataupun argumen), serta membuat keputusan yang didasarkan dengan adanya bukti.

Dengan guru melakukan model pembelajaran yang kooperatif, siswa bisa berpartisipasi dengan baik dan bisa berfikir dengan sendirinya. Maka dari itu harus mencari model pembelajaran yang tepat untuk membantu siswa belajar dengan baik. Menurut Sanjaya (2010, p.196), strategi pembelajaran inkuiri adalah rangkaian kegiatan pembelajaran yang menekankan pada proses berfikir secara kritis dan analitis untuk mencari dan menemukan sendiri jawaban yang sudah pasti dari suatu masalah yang ditanyakan. 
Proses berfikir itusendiri biasanya dilakukan melalui tanya jawab antara guru dan siswa. Strategi pembelajaran ini sering juga dinamakan strategi heuristic, yang berasal dari bahasa Yunani, yaitu heuriskein yang berarti saya menemukan.

Dengan demikian siswa akan mampu berpikir kritis dalam belajar apabila guru mampumengembangkan proses pembelajaran yang menuntut keterlibatan siswa secara aktif didalamnya sehingga kemampuan berpikir siswa akan berkembang dengan masalah dan tantangan yang dihadapinya. Berpikir kritis secara sederhana menyatakan kemampuan untuk menganalisis dan mengevaluasi informasi. Menurut Dewi (2013), model pembelajaran inkuiri terbimbing menekankan pada prosespenemuan sebuah konsep sehingga muncul sikap ilmiah pada diri siswa dan dapat dirancangpenggunaannya oleh guru menurut tingkat perkembangan intelektual siswa. Kegiatan pembelajaran di kelas melibatkan beberapa komponen pembelajaran, di antaranya: perencanaan, tujuan, bahan atau materi pembelajaran, strategi, metode, teknik, media, dan evaluasi. Seorang guru harus terampil dan kreatif dalam merancang pembelajaran. Guru dituntut memiliki kemampuan dalam memilih metode pembelajaran, salah satunya adalah metode inkuiri (Kristiyani, 2010).

Menurut Sumarmi (2012) Model pembelajaran Group Investigation (GI) merupakan pembelajaran kooperatif yang melibatkan kelompok kecil, siswa menggunakan inkuiri kooperatif (perencanaan dan diskusi kelompok) kemudian mempresentasikan penemuan mereka di kelas. Model pembelajaran Group Investigation (GI) memiliki beberapa kelebihan dibandingkan dengan model pembelajaran kooperatif lainnya. Kelebihan Group Investigation (GI) menurut Sharan dan sharan (dalam Sumarmi, 2012) yaitu: 1) siswa yang berpartisipasi dalam GI cenderung berdiskusi dan menyumbangkan ide tertentu, 2) gaya bicara dan kerjasama siswa dapat diobservasi, 3)siswa dapat belajar kooperatif lebih efektif, dengan demikian dapat meningkatkan interaksi sosial mereka, 4) GI dapat mendorong siswa untuk berpartisipasi aktif, sehingga pengetahuan yang diperoleh dapat ditransfer ke situasi diluar kelas, 5) GI mengijinkan guru untuk lebih informal, 6) GI dapat meningkatkan penampilan dan prestasi belajar siswa. Maka dari itu penelitian ini mengambil judul "Penerapan Metode Pembelajaran Inkuiri dan group investigation (GI) pada pembelajaran PJOK terhadapPartisipasi dan Berpikir kritis Siswa SMPN 4 Pamekasan.

\section{METODE}

Metode penelitian ini adalah penelitian kuasi eksperimen, karena penelitian ini cara pengambilan sampel tidak dilakukan secara acak. Desain penelitian dibuat untuk membentuk sebuah susunan rancangan atau langkah- langkah melakukan sebuah penelitian. Berdasarkan jenis variabel yang digunakan dalam penelitian ini, maka non randomized control group pretest- posttest desing adalah sebutan yang tepat. Desain penlitian seperti pada Tabel 1 .

Tabel 1. Desain Penelitian

\begin{tabular}{cccc}
\hline$K . E_{1}$ & $T_{1}$ & $X_{1}$ & $T_{2}$ \\
\hline$K . E_{2}$ & $T_{1}$ & $X_{2}$ & $T_{2}$ \\
\hline$K . K$ & $T_{1}$ & $X_{3}$ & $T_{2}$ \\
\hline
\end{tabular}

Keterangan

$K . E_{1}=$ Kelompok 1

$K . E_{2}=$ Kelompok 2

$K . K=$ Kelompok Kontrol

$T_{1}=$ Pretest

$X_{1}=$ Treatment Model Pembelajaran

Inkuiri

$X_{2}=$ Treatment Model Pembelajaran

Group Investigation

$X_{3}=$ Non Treatment

$T_{2}=$ Posttest

Cluster random sampling adalah teknik pengambilan sampel yang akan digunakan dalam penelitian ini. Sebanyak 3 kelas dengan keseluruhan sampel (76 siswa) dengan tiap kelasnya 25 siswa dan 26 siswa dan terpilihlah kelas VIII B diberikan perlakuan metode inkuiri, VIII C diberikan perlakuan group investigation, VIII A tidak diberikan perlakuan atau diberikan perlakuan yang memang diberikan oleh gurunya disekolah. Penelitian ini dilakukan di SMPN 4 Pamekasan dan treatment yang diberikan adalah model pembelajaran Inkuiri dan model pembelajaran 
Group Investigation (GI) dalam proses pembelajaran PJOK. Partisipasi belajar diukur menggunakan instrumen lembar obeservasi partisipasi, dengan perhitungan:

Jarak Interval $=\frac{\text { skor tertinggi }- \text { skor terendah }}{\text { jumlah kelas interval }}$

Tabel 2. Ketentuan Partisipasi Siswa

\begin{tabular}{cc}
\hline Skor & Kategori \\
\hline $3,26-4,00$ & Sangat tinggi \\
$2,57-3,25$ & Tinggi \\
$1,76-2,56$ & Sedang \\
$1,00-1,75$ & Rendah \\
\hline
\end{tabular}

untuk menafsirkan, menganalisis, mengevaluasi (suatu ide, hasil observasi, informasi, ataupun argumen), serta membuat keputusan yang didasarkan dengan adanya bukti. Peningkatan kemampuan berpikir kritis yang terjadi sebelum dan sesudah pembelajaran dihitung dengan rumus gain ternormalisasi dengan rumus (Meltzer, 2002).

$$
\mathrm{g}=\frac{\text { skor postest-skor pretest }}{\text { skor maksimum-skor pretest }}
$$

Perhitungan indeks gain kemudian diinterpretasikan dengan menggunakan kategori menurut Hake (Meltzer, 2002) yaitu:

Tabel 3. Klasifikasi Normalisasi Gain

\begin{tabular}{cc}
\hline Nilai n-gain & Klasifikasi \\
\hline $\mathrm{g}<0,3$ & Rendah \\
$0,3 \leq \mathrm{g}<0,7$ & Sedang \\
$\mathrm{g} \geq 0,7$ & Tinggi \\
\hline
\end{tabular}

Selanjutnya data dianalisis secara statistik dengan uji normalitas, homogentias, dan uji hipotesis (uji-t). Uji normalitas yang akan digunakan bertujuan untuk memastikan bahwa data yang diperoleh berdistribusi simetris atau normal. Untuk menguji normalitas menggunakan dengan metode Kolomogrov Seminorv (Maksum, 2012). Agar bisa menentukan normalitasnya yaitu dengan membandingkan taraf signifikan perhitungan yang data dengan taraf 5\% jika taraf signifikasi dalam uji statistic lebih besar dari 0,05 maka bisa dinyatakan data berdistribusi normal. Uji homogenitas bertujuan untuk memastikan bahwa varian kelompok sama atau sejenis, sehingga perbandingan dapat dilakukan secara adil. Pada penelitian ini digunakan Lavene's test. Apabila nilai statistic lavene lebih besar dari 0,05 maka data memiliki varian yang homogenitas. Uji signifikan ( $t_{\text {hitung }}$ ) memiliki syarat data harus berdistribusi normal (Sujarweni, 2015). Uji ini bertujuan untuk mengetahui apakah sampel memiliki perbedaan nyata dengan sampel yang lain. Uji hipotesis menggunakan independent sample ttest, uji ini digunakan untuk menghitung ratarata dua sampel dari grup yang tidak saling berhubungan, bertujuan untuk mengetahui apakah kedua grup memiliki rata-rata yang sama. Langkah pertama melihat nilai sig $F_{\text {hitung }}>\quad 0,05$ maka $H_{0}$ diterima, dan dinyatakan ditolak $H_{0}$ ditolak jika nilai sig $F_{\text {hitung }}<0.05$. Langkah kedua, jika nilai sig $t_{\text {hitung }}>0.05$ maka $H_{0}$ diterima, dan dinyatakan $H_{0}$ ditolak jika nilai sig thitung $<$ 0,05 . Selanjutnya paired sample t-test digunakan untuk menghitung rata-rata dua sampel yang saling berhubungan dan menentukan ada tidaknya perbedaan kedua sampel tersebut. Sujarweni (2015) menyatakan jika tipe sampel interval atau rasio dan berdistribusi normal maka menggunakan uji ini, namun jika tidak berdistribusi normal maka disarankan menggunakan uji non parametric untuk uji sampel yangberpasangan. Hasil yang didapat dikatakan diterima $\left(H_{0}\right.$ diterima) jika nilai sig $>0,05$ dan dinyatakan ditolak $\left(H_{0}\right.$ ditolak) jika nilai sig $<0,05$.

\section{HASIL DAN PEMBAHASAN}

Penelitian ini menggunakan dua kelompok penelitian (8B dan 8C) dan satu kelompok kontrol (8A) terhadap partisipasi dan berpikir kritis siswa. Data yang akan dipaparkan adalah deskripsi dari keseluhan data yang diambil dari penelitian ini, yaitu : (1) Data pre-test kelompok penelitian dan kontrol dengan dua variabel terikat partisipasi dan berpikir kritis, (2) Data post-test kelompok penelitian dan kontrol dengan dua variabel terikat partisipasi dan berpikir kritis, dengan jumlah sampel 26 sama 25 siswa kelas 8 di SMP Negeri 4 Pamekasan sebanyak 2x pertemuan selama 2 minggu pembelajaran PJOK yang bisa dilihat pada Tabel 4 dan 5 . 
Tabel 4. Deskripsi Hasil Pretest (Data Awal)

Tabel 5. Deskripsi hasil posttest (Data akhir)

\begin{tabular}{lllllll}
\hline Kelompok & Variabel & $\mathrm{N}$ & Min & Max & Mean & Std.Dev \\
\hline Inkuiri (8B) & Partisipasi & 26 & 65 & 96 & 79,61 & 8,22 \\
& Berpikir & 26 & 16 & 40 & 27,15 & 5,68 \\
& Kritis & & & & & \\
\hline GI (8C) & Partisipasi & 25 & 55 & 95 & 73,92 & 8,78 \\
& Berpikir & 25 & 15 & 34 & 26,36 & 4,75 \\
& Kritis & & & & & \\
\hline K (8A) & Partisipasi & 25 & 55 & 87 & 72,28 & 8,61 \\
& Berpikir & 25 & 15 & 35 & 23,48 & 4,91 \\
& Kritis & & & & & \\
\hline
\end{tabular}

Tabel 4 dan tabel 5 mendeskripsikan data pre dan post-test yang digunakan untuk mengetahui ada tidaknya pengaruh dan ada tidaknya beda pengaruh yang diberikan oleh model pembelajaran. Tabel 6 menjabarkan nilai rerata dari pre dan post hasil penelitian.

Tabel 6. Hasil uji coba pretest dan posttest

\begin{tabular}{clccccc}
\hline Kelompok & Variabel & $\mathrm{N}$ & Pretest & Posttest & Selisih & Presentase \\
\hline Inkuiri (8 B) & Partisipasi & 26 & 78,30 & 79,61 & $+1,31$ & $5,0 \%$ \\
& Berpikir Kritis & 26 & 24,84 & 27,15 & $+2,31$ & $8,8 \%$ \\
\hline GI (8 C) & Partisipasi & 25 & 72,08 & 73,92 & $+1,84$ & $7,3 \%$ \\
& Berpikir Kritis & 25 & 22,56 & 26,36 & $+3,8$ & $15,2 \%$ \\
\hline K (8 A) & Partisipasi & 25 & 71,36 & 72,28 & $+0,92$ & $3,6 \%$ \\
& Berpikir Kritis & 25 & 23,12 & 23,48 & $+0,36$ & $1,4 \%$
\end{tabular}

Pada kelompok sampel, data penelitian didapatkan dari hasil hitung 26 dan 10 item pernyataan pada angket partisipasi dan berpikir kritis. Peningkatan terjadi pada seluruh kelompok sampel pada variabel partisipasi dan berpikir kritis.

Data perubahan di atas diubah menjadi grafik agar mudah untuk dipahami seperti pada gambar 1 .

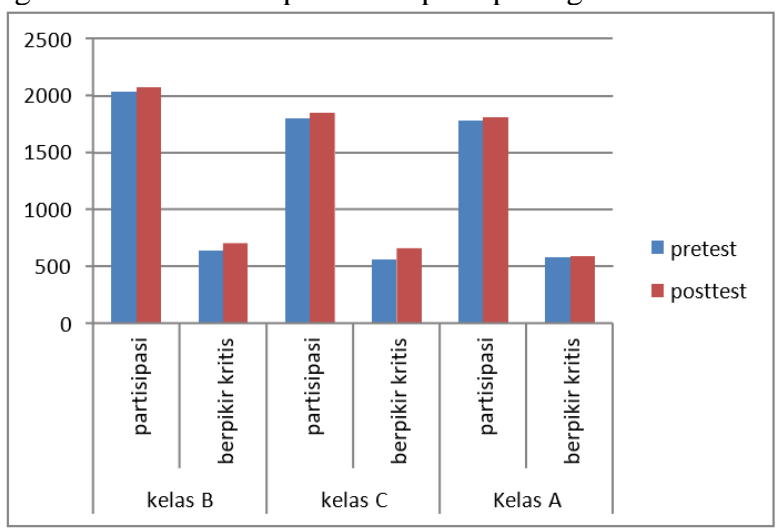

Gambar 1. Hasil pretest dan posttest tiap-tiap kelas

Berdasarkan hasil Gambar 1, pada kelas B yang dikasih metode Inkuiri mengalami peningkatan yang tidak terlalu tinggi terhadap partisipasi dengan selisih pretest dan posttest 1,31 , sedangkan berpikir kritis selisihnya 2,31, kelas C yang dikasih group investigation mengalami peningkatan yang tinggi terhadap partisipasi dengan selisih 1,84 , sedangkan berpikir kritis 3,8, pada kelas A yang tidak dikasih metode pembelajaran juga ada peningkatan meskipun sedikit terhadap partisipasi dengan selisih 0,92 , dan berpikir kritis selisih 0,36 . Selanjutnya, hasil uji normalitas dan homogenitas ditunjukkan pad Tabel 7 dan 8, dimana hasil menunjukkan bahwa data terdistribusi normal dan varian data homogen.

Tabel 7. Hasil uji normalitas

\begin{tabular}{|c|c|c|c|c|c|c|}
\hline Variabel & Test & Inkuiri & GI & KK & Ket. & $\begin{array}{l}\text { Status } \\
\text {. }\end{array}$ \\
\hline & & Sig & Sig & Sig & & \\
\hline \multirow[t]{2}{*}{ Partisipasi } & Pre & 0,943 & 0,971 & 0,510 & $P>0,05$ & Normal \\
\hline & Post & 0,819 & 0,994 & 0,766 & $P>0,05$ & Normal \\
\hline \multirow[t]{2}{*}{ Berpikir Kritis } & Pre & 0,826 & 0,967 & 0,631 & $P>0,05$ & Normal \\
\hline & Post & 0,481 & 0,587 & 0,721 & $\mathrm{P}>0,05$ & Normal \\
\hline
\end{tabular}

\begin{tabular}{ccccc}
\hline Tabel 8. Hasil Uji Homogen & \\
\hline Variabel & Test & Sig & Ket & Status \\
\hline Partisipasi & Pre & 0,680 & $\mathrm{P}>0,05$ & Homogen \\
& Post & 0,834 & $\mathrm{P}>0,05$ & Homogen \\
Berpikir Kritis & Pre & 0,438 & $\mathrm{P}>0,05$ & Homogen \\
& Post & 0,514 & $\mathrm{P}>0,05$ & Homogen \\
\hline
\end{tabular}

Selanjutnya dilakukan uji hipotesis degan uji $t$ (paired sample $t$ ), masing-masing pada kelas uji untuk partisipasi dan berpikir kritis ditunjukkan pada Tabel 9 dan Tabel 10.

Tabel 9. Uji beda paired sample $\mathrm{t}$ test partisipasi (pretest dan posttest)

\begin{tabular}{lccccc}
\hline $\begin{array}{l}\text { Pretest- } \\
\text { Posttest }\end{array}$ & Mean & $\begin{array}{c}\text { Std } \\
\text { Dev. }\end{array}$ & T & Df & $\begin{array}{c}\text { Sig }(2 \\
\text { Tailerd })\end{array}$ \\
\hline Inkuiri & -1.307 & 2.204 & $-3,024$ & 25 & 0,006 \\
GI & -1.840 & 2.014 & $-4,568$ & 24 & 0,000 \\
Kontrol & -9.200 & 2.253 & $-2,042$ & 24 & 0,052 \\
\hline
\end{tabular}

Tabel 10. Uji beda paired sample $t$ test berpikir kritis (pretest dan posttest)

\begin{tabular}{lccccc}
\hline $\begin{array}{l}\text { Pretest- } \\
\text { Posttest }\end{array}$ & Mean & $\begin{array}{c}\text { Std } \\
\text { Dev. }\end{array}$ & T & Df & $\begin{array}{c}\text { Sig (2 } \\
\text { Tailerd) }\end{array}$ \\
\hline Inkuiri & -2.307 & 2.753 & $-4,274$ & 25 & 0,000 \\
GI & -3.800 & 2.929 & $-6,485$ & 24 & 0,000 \\
Kontrol & 2,800 & 1.400 & -1.000 & 24 & 0,327 \\
\hline
\end{tabular}

Uji beda paired sample t test kelompok Inkuiri (0,006), Group Investigation $(0,000)$, pada kelompok kontrol $(0,052)$, pada kelompok penelitian menunjukkan nilai < 0,05 , maka $H_{0}$ ditolak, sedangkan kelompok kontrol menunjukkan nilai $>0,05$, maka $H_{0}$ diterima, yang berarti ada perbedaan partisipasi pada pretest dan posttest ketiga kelompok tersebut. Uji paired sample $t$ test pada berpkir kritis kelompok Inkuiri $(0,000)$, 
Terakreditasi Peringkat 4 (No. SK: 36/E/KPT/2019)

Group Investigation $(0,000)$ menghasilkan < 0,05 maka $H_{0}$ ditolak sehingga ada perbedaan yang signifikan pada berpikir kritis siswa, sedangkan kelompok kontrol $(0,327)$ tidak. Berdasarkan hasil ini disimpulkan bahwa metode pembelajaran inkuiri dan group investigation terhadap partisipasi di SMPN 4 pamekasan, terdapat pengaruh yang signifikan pada kelas yang di ambil sampelnya, tapi yang lebih signifikan pada kelas group investigation.

Dalam metode inkuiri siswa dirancang untuk terlibat dalam melakukan inkuiri. Metode ini merupakan metode pembelajaran tang berpusat pada siswa Jadi dapat disimpulkan bahwa metode pembelajaran inkuiri adalah kegiatan pembelajaran yang melibatkan seluruh kemampuan siswa untuk mencari dan menyelidiki suatu masalah secara kritis, logis, dan analisis sehingga siswa dapat menemukan jawaban atau pemecahan dari masalah tersebut. Menurut Sanjaya (2010, p.196), strategi pembelajaran inkuiri adalah rangkaian kegiatan pembelajaran yang menekankan pada proses berfikir secara kritis dan analitis untuk mencari dan menemukan sendiri jawaban yang sudah pasti dari suatu masalah yang ditanyakan. Model pembelajaran inkuiri digunakan didalam kelas dengan cara menggunakan angket yang sudah ada sehingga dalam pengapliasiannya siswa belajar dan praktek di kelas. Pada penerapan dikelas sampel yang digunakan pada metode pembelajaran inkuiri sejumlah 26 siswa, didalam pembelajaran PJOK dengan menggunakan menggunakan metode inkuiri ini siswa ada yang aktif atau bisa berpikir kritis dan memecahkan masalahnya sendiri. Berdasarkan dari hasil penelitian angket partisipasi siswa mengalami peningkatan rerata $5,0 \%$ dengan menggunakan metode inkuiri dalam pembelajaran PJOK didalam kelas, sedangkan angket berpikir kritis juga mengalami kenaikan 8,8\% selama penelitian.

Salah satu tipe pembelajaran kooperatif yang efektif untuk meningkatkan minat dan hasil belajar adalah group investigation (GI) berbantuan media flanelgraf. Group investigation merupakan penemuan yang dilakukan siswa secara berkelompok melakukan pekerjaan dengan aktif, yang memungkinkan mereka menemukan suatu prinsip (Slavin dalam Kesuma, 2013). Group investigation membantu guru untuk mengaitkan antara materi dengan keadaannya siswa serta mendorong siswa menerapkan pe getahuan dalam kehidupan mereka (Kesuma, 2013).

Group investigation adalah salah satu metode pembelajaran kooperatif berbasis penemuan dimana setiap kelompok berangggotakan 4-6 orang dengan komposisi kelompok heterogen (Rusman, 2010).Langkah- langkah group investigation berbantuan media flanelgraf dalam pembelajaran yaitu membentuk kelompok dan pemilihan topik, merencanakan penyelesain topik, melakukan investigasi berbantuan media flanelgraf, penyusunan laporan, mempresentasikan laporan, dan evaluasi. Dari hasil penelitian ditunjukkan bahwa dengan metode group investigation, partisipasi mengalami peningkatan rerata $7,3 \%$ dengan menggunakan group Investigation dalam pembelajaran PJOK didalam kelas, sedangkan angket berpikir kritis juga mengalami kenaikan $15,2 \%$ selama penelitian.

Penelititian ini menngunakan 3 sampel kelas yang terbagi menjadi kelompok penelitian inkuiri 1, kelompok penelitian group investigation 2, dankelompok penelitian kontrol. Berdasarkan dari hasil penelitian angket partisipasi siswa mengalami peningkatan rerata 5,0\% dengan menggunakan metode inkuiri dalam pembelajaran PJOK didalam kelas, sedangkan angket berpikir kritis juga mengalami kenaikan $8,8 \%$ selama penelitian, sedangkan group investigation juga mengalami peningkatan partisipasi $7,3 \%$ dan berpikirkritis presentasenya $15,2 \%$, dan kelas kontrol juga mengalami kenaikan meskipun tidak terlalu tinggi dengan hasil presentase partisipasi sebesar 3,6\% dan berpikir kritis sebesar $1,4 \%$. Berdasarkan keterangan diatas penerapan metode inkuiri dan group investigation pada partisipasi dan berpikir kritis dalam pembelajaran PJOK menunjukkan peningkatan yang signifikan pada berpikir kritis. Meskipun inkuiri dalam penelitian ini tidak terlalu tinggi peningkatannya, sedangkan group investigation sangat tinggi peningkatannya terhadap peningkatan berpikir 
Terakreditasi Peringkat 4 (No. SK: 36/E/KPT/2019) kritis, hal ini menjadikan hasil belajar siswa sangat tergantung pada jenis metode pembelajaran yang diberikan oleh guru.

\section{KESIMPULAN}

Terdapat pengaruh pemberian metode inkuiri terhadap nilai rata-rata partisipasi siswa yaitu dari 78,30 menjadi 79,61 dengan peningkatan sebesar 5\%, dan berpikir kritis yaitu 24,84 menjadi 27,15 dengan presentase peningkatan sebesar $8,8 \%$, hal ini menunjukkan bahwai metode pembelajaran diatas mengalami peningkatan yang signifikan. Terdapat pengaruh pemberian group investigation terhadap nilai rata-rata partisipasi siswa yaitu dari 72,08 menjadi 73,92 dengan peningkatan sebesar 7,3\% dan berpikir kritis yaitu 22,56 menjadi 26,36 dengan presentase peningkatan sebesar $15,2 \%$, hal ini menunjukkan bahwa metode pembelajaran diatas mengalami peningkatan yang sangat signifikan. Pada kelompok kontrol, kenaikan rerata partisipasi sebesar $3,6 \%$ dan kenaikan berpikir kritis 1,4\% penerapan pembelajaran PJOK pada kelompok pembelajaran metode inkuiri, group investigation, dan kontrol mengalami kenaikan antara nilai rata-rata pretest dan posttest baik terhadap partisipasi maupun berpikir kritis. Dari hasil presentase peningkatan ketiga kelompok tersebut, kelompok group investigation merupakan kelompok yang peningkatannya lebih tinggi terhadap partisipasi dan berpikir kritis dari pada metode inkuiri.

\section{DAFTAR PUSTAKA}

Anne O'keeffe, Steve Walsh, (2012), Applying corpus linguistics and conversation analysis in the investigation of small group teaching in higher education, Corpus Linguistics and Linguistic Theory 8-1, 159 - 181, DOI 10.1515/cllt- 2012-0007

Arikunto, Suharsimi. 2002. Prosedur Penelitian Suatu Pendekatan Praktek. Jakarta: Rineka Cipta.

Bilal Khalid Khalaf, Zuhana Bt Mohammed Zin, (2018), Traditional and InquiryBased Learning Pedagogy: A Systematic Critical Review,
International Journal of Instruction, Vol.11, No.4, ISSN: 1308-1470

Budiada,I Wayan. 2012.”Pengaruh penerapan model pembelajaran inkuiri terbimbing berbasis asesmen portofolio terhadap hasil belajar kimia siswa kelas $x$ ditinjau dari adversity quotient". Jurnal, Program Pasca Sarjana UNDHIKSA.Vol 2 No.1 (2012)

Budiningsih, Asri. 2005. Belajar Dan Pembelajaran. Jakarta: Rinekacipta.

Caswell, C. J. and LaBrie, D. J. (2017) "Inquiry Based Learning from the Learner's Point of View: A Teacher Candidate's Success Story," Journal of Humanistic

Mathematics, Volume 7 Issue 2, pages 161-186. DOI: 10.5642/jhummath.201702.08

Christinsenia Seranica, Agus Abhi Purwoko, Aliefman Hakim, (2018), Influence of Guided Inquiry Learning Model to Critical Thinking Skills, IOSR Journal of Research \& Method in Education, Volume 8, Issue 1 Ver. II, PP 28-31, ISSN: 2320-7388

Đbrahim Yasar Kazu, (2009), The Effect Of Learning Styles On Education And The Teaching Process, Journal Of Social Sciences 5(2): 85-94, ISSN 1549-3652

Depdiknas. (2001). Manajemen peningkatan mutu berbasis sekolah. Buku 1 Konsep dan Pelaksanaan. Jakarta: Depdik-nas.

Dimyati dan Mujdiono. 2009. Belajar dan

Pembelajaran. Jakarta: Penerbit Rineka Cipta.

Eli Widoyo Retno, Mardiyana, Tri Atmojo Kusmayadi. (2014). Pengembangan Model Pembelajaran Group Investigation (Gi) Berbantu Video Camtasia Pada Materi Peluang Untuk Siswa Sma/Ma Negeri Kabupaten Cilacap Tahun Pelajaran 2013/2014. Jurnal Elektronik Pembelajaran Matematika. Issn: 2339-1685 Vol.2, No.5, Hal 478- 490.

Eva Wardanis, (2016), Peningkatan Partisipasi

Belajar Siswa Kelas Vi Pada Pembelajaran Pkn Dengan Menggunakan Model Guided Teaching 
Di Sdn 17 Batang Anai Kabupaten

Padang Pariaman, Jurnal Konseling

Dan

Pendidikan,

Http://Jurnal.Konselingindonesia.Com

, Vol. 4 No. 4. Hlm. 29-38

Euis Istianah, (2013), Meningkatkan

Kemampuan Berpikir Kritis Dan

Kreatif Matematik Dengan Pendekatan

Model Eliciting Activities (Meas) Pada

Siswa Sma, Jurnal Ilmiah Program

Studi Matematika STKIP Siliwangi

Bandung, Vol 2, No.1

Fakhra Aziz, Uzma Quraishi*, Asma Shahid

Kazi, (2018), Factors Behind

Classroom Participation Of Secondary

School Students (A Gender Based

Analysis), Universal Journal Of

Educational Research 6(2): 211-217

Hasnawati, (2017), Model Berbasis Portofolio

Untuk Meningkatkan Partisipasi

Belajar Siswa Pada Pembelajaran Pkn,

Jurnal Penelitian Pendidikan

Indonesia, Http:// Jurnal. Iicet. Org |

Doi

Https://Doi.Org/10.29210/02017105,

Volume 1 Nomor 3, Hlm 19-26

Haji Hamidun Sitorus1, Hasruddin1, Syahmi Edi, (2017), The Influence of Inquiry Learning Model on Student's Scientific Attitudes in Ecosystem Topic at MTs. Daarul Hikmah Sei Alim (Islamic Junior High School) Asahan, International Journal of Humanities Social Sciences and Education, Volume 4, Issue, PP 170-175, ISSN 2349-0381.

Hani Nur'azizah, Asep Kurnia Jayadinata, Diah Gusrayani, (2016), Pengaruh Model Pembelajaran Inkuiri Terbimbing Terhadap Kemampuan Berpikir Kritis Siswa Pada Materi Energi Bunyi, Jurnal Pena Ilmiah: Vol. 1, No. 1 .

Israwani. (2015). Penggunaan Model Pembelajaran Inkuiri Pada Materi Operasi Hitung Bilangan Di Kelas I Sd Negeri 53 Banda Aceh. Jurnal Peluang, Volume 3, Nomor 2, ISSN: 2302-5158

I Putu Artayasa, Herawati Susilo, Umie Lestari, Sri Endah Indriwati, (2018), The Effect of Three Levels of Inquiry on the Improvement of Science
Concept Understanding of Elementary School Teacher Candidates, International Journal of Instruction, Vol.11, No.2, ISSN: 1308-1470.

Las Johansen Balios Caluza, Ma. Victoria A. Diaz, Romyr Gabon, (2015), The Use Of Teaching Styles In Physical Education Perceived By Graduate Students, International Journal Of Education And Research, Vol. 3 No. 3

Naim Bey Khaqi Asmara Putra, Sudarso, (2014), Pengaruh Model Pembelajaran Inkuiri Terhadap Hasil Belajar Dribbling Dalam Permainan Bola Basket, Jurnal Pendidikan Olahraga dan Kesehatan, Volume 02 Nomor 03, $761-764$.

Nurhayati, (2017), Peningkatan Partisipasi Dan Hasil Belajar Siswa Kelas Iva Dalam Pembelajaran Pai Dengan Strategi True Or False Di Sd Negeri 21 Batang Anai, Jurnal Penelitian Pendidikan Indonesia, Http://Jurnal.Iicet.Org | Doi Https://Doi.Org/10.29210/02017115, Volume 3 Nomor 2, Hlm 30-43.

Mushoddik, Sugeng Utaya, Budijanto. (2016). Pengaruh Model Pembelajaran Group Investigation Terhadap Kemampuan Berpikir Kritis Siswa Man 6 Jakarta. Issn 2250-1321 (Online), Issn 20852436 (Print) Geo Edukasi Vol. 5, No.2,

Maksum, A. (2012) Metodologi Penelitian dalam Olahraga. Surabaya: FIK Universitas Negeri Surabaya.

Mulyasa. 2006. Belajar Dan Berpartisipasi Aktif Dalam Pendidikan Tinggi. Jakarta : Aneka Pustaka.

Masha Smallhorn, Jeanne Young, Narelle Hunter, Karen Burke da Silva, (2015), Inquiry-based learning to improve student engagement in a large first year topic, Student Success, Volume 6, Issue 2, pp. 65-71, ISSN: 2205-0795.

Pinar Simsek, Filiz Kabapinar, (2010), The effects of inquiry-based learning on elementary students conceptual understanding of matter, scientific process skills and science attitudes, Elsevier, doi:10.1016/j.sbspro.2010.03.170 
Terakreditasi Peringkat 4 (No. SK: 36/E/KPT/2019)

Rasulun Iman, Ibnu Khaldun, Nasrullah, (2017), Meningkatkan Kemampuan Berpikir Kritis Siswa Dengan Model Inkuiri Terbimbing Pada Materi Pesawat Sederhana, Jurnal Pendidikan Sains Indonesia, Vol. 05, No.01.

Randy Borum, Psy. D, Marisa Reddy, Ph.D, (2001), Assessing Violence Risk in Tarasoff Situation: A Fact-Based Model of Inquiry, Behavioral Sciences and the law, 19:, 375-385, DOI: 10. 1002/bsl.447.

Rosmaulina Adelina Ambarita, Yunastiti, Mintasih Indriayu, (2019), The Application of Group Investigation Based on Hands on Activities to Improve Learning Outcomes Based on Higher Order Thinking Skills of Students at SMA Negeri 2 Pematangsiantar, Budapest International Research and Critics in Linguistics and Education (BirLE) Journal, Volume 2, No 2, May 2019, Page: 351-359 e-ISSN: 2655-1470

Seyed Mohammad Hassan Hosseini, (2014), Competitive Team-Based Learning versus Group Investigation with Reference to the Language Proficiency of Iranian EFL Intermediate Students, International Journal of Instruction, Vol.7, No., ISSN: 1308-1470.

Sri Usdalifat, Achmad Ramadhan, dan Samsurizal M. Suleman, (2016), Pengaruh Model Pembelajaran Inkuiri Terhadap Kemampuan Berpikir Kritis Dan Keterampilan, Jurnal Sains dan Teknologi Tadulako, Volume 5, ISSN: 2089-8630.

Sylvia Hayyu Lestari, Heryanto Nur Muhammad, (2013), Penerapan Metode Inquiry Pada Pembelajaran Pendidikan Jasmani Terhadap Hasil Belajar Chest Pass Bola Tangan, Jurnal Pendidikan Olahraga dan Kesehatan, Volume 01 Nomor03, 529 $-534$

Sujarweni, V. Wiratna. 2015. SPSS untuk Penelitian. Yogyakarta : Pustaka Baru Press.

Tamren, (2017), Penerapan Metode Inkuiri Pada Mata Pelajaran Penjaskes Untuk
Meningkatkan Motivasi Belajar Teknik Bermain Bola Volly Siswa Kelas Xi Ak 1 Smk Negeri 1 Meulaboh Tahun Ajaran 2016/2017, Variasi, Volume 9, Nomor 1, Issn : 2085-6172

Truong Anh Tuan, Storch Neomy, (2007), Investigating Group Planning in Preparation for Oral Presentations in an EFL Class in Vietnam, Vol 38(1) 104-124 DOI: $10.1177 / 0033688206076162$

Vera Septi Andrini, (2016), The Effectiveness of Inquiry Learning Method to Enhance Students' Learning Outcome: A Theoritical and Empirical Review, Journal of Education and Practice, Vol.7, No.3.

Yenni Anas, Hardeli, Azwir Anhar, Ramadhan Sumarmin, (2018), Application of Type Cooperative Learning Models Group Investigation (GI) in Improving Competence Learning Biology Student School, International Journal of Progressive Sciences and Technologies, Vol. 6 No. 2 pp. 380387. 